\title{
How widespread were private investment and regulatory reform in infrastructure utilities during the $1990 \mathrm{~s}^{1}$
}

\author{
Antonio Estache and Ana Goicoechea \\ The World Bank, INFVP
}

\begin{abstract}
This note provides a snapshot as of 2004 of the share of countries with an "independent" regulatory agency and with at least some private sector financing of its sectoral investment needs for electricity, water and sanitation and telecoms. Among other things, it shows that:

- For respectively, electricity, water and sanitation, and telecoms, $51 \%, 21 \%$ and $66 \%$ of the developing countries in the sample have an "independent" regulator; i.e. an agency separate from a Ministry and from the operator.

- For respectively, electricity generation, electricity distribution, water and sanitation, and telecoms, $47 \%, 36 \%, 35 \%$ and $59 \%$ of the developing countries in the sample have at least some private sector financing.

- The shares of both agencies and private sector involvement tend to increase with income levels.

- Latin and Central America and Eastern Europe are outliers among regions as almost systematically they have among the highest shares for both indicators across sectors (except water).
\end{abstract}

\section{World Bank Policy Research Working Paper 3595, May 2005}

The Policy Research Working Paper Series disseminates the findings of work in progress to encourage the exchange of ideas about development issues. An objective of the series is to get the findings out quickly, even if the presentations are less than fully polished. The papers carry the names of the authors and should be cited accordingly. The findings, interpretations, and conclusions expressed in this paper are entirely those of the authors. They do not necessarily represent the view of the World Bank, its Executive Directors, or the countries they represent. Policy Research Working Papers are available online at http://econ.worldbank.org.

\footnotetext{
${ }^{1}$ We are grateful to colleagues across the multilateral development agencies for their help in generating this information. We are particularly grateful to Ian Alexander, Inger Andersen, Pierre Audinet, Jean-Francis Benhamou, Philippe Benoit, John Besant-Jones, Jaime Biderman, Jose Carbajo, Vivien Foster , Katarina Gassner, Eric Groom, Jose-Luis Guasch, Jose-Luis Irigoyen, David Kennedy, Fabienne Ilzkovitz, Nigel Ings, Phil Lam, Anat Levin, Augustin Mapapa Mbangala, Fatimata Ouedraogo, Eustache Ouayoro, Sergio Perelman, Maria Elena Pinglo, Martin Rodriguez Pardina, Gary Stuggins, Gaetane Tracz, Lourdes Trujillo, Caroline van den Berg, Richard Verspyck, Quentin Wodon, Tito Yepes and Christine Zhen-Wei Qiang,
} 


\section{Introduction}

As the debate on the optimal infrastructure reform design heats up again in the development community, it seems useful to take stock of how much reform actually took place during the 1990s. This stocktaking is warranted because the generic debate tends to be much more dogmatic, or at least emotional, than based on facts. Among the many implicit assumptions built in these debates on infrastructure sector reforms in the 1990s, two stand out: (i) private operators have taken over the main dimensions of infrastructure service delivery and (ii) independent regulatory agencies (i.e. agencies separated from the Ministry and from the incumbent operator) have been created to supervise the residual private infrastructure monopolies in the sectors. $^{2}$

The main purpose of this note is to report the results of a 2004 survey designed to provide a baseline on these two very basic dimensions of the reforms. The idea is to get an up-to-date rough snapshot of the extent to which the various regions of the world have actually introduced some private sector participation in infrastructure sectors and have created separate regulatory agencies. A few much more ambitious sector specific surveys have been conducted over the last five years or so (examples are Bacon and Besant-Jones (2001) for electricity, and Halpern (2002) for water) but these are already somewhat out of date. This note is not as rich in substantive coverage or as subtle in the design as these earlier surveys but it has the advantage of covering a much larger set of sectors and countries. Depending on the sectors, our sample sizes range from 124 to 207 countries, including developing, OECD and non-OECD developed countries.

The survey reflects the situation as of mid-2004. It was conducted between August and mid-November 2004. It draws on four main sources: (i) the publications of international or bilateral agencies (ITU, IEA, WHO, EEC, DFID, GTZ, AFD, ADB, IDB, and EBRD among others); (ii) the databases collected as part of research efforts and made available to other researchers in public sources (the research department at the World Bank, AEI- Brookings, and independent academic researchers); (iii) the desk officers for each sector in international organizations; (iv) government officials working on the relevant sectors.

When sending questionnaires or interviewing individuals the two specific questions asked were as follows: (a) Has a regulatory body that is separate from the utility and from the Ministry started to work? ${ }^{3}$ (b) Is there any (significant) private participation in the financing of the sector? ${ }^{4}$ The information collected does not say anything about the intensity or the share of the private sector contribution to the sector and it is well known that the relative importance of the private sector in a given infrastructure activity varies

\footnotetext{
${ }^{2}$ A third dimension commonly mentioned is the unbundling of the sector. But this has many more facets and is hence less simple to summarize than the two dimensions discussed in this paper.

${ }^{3}$ Note that, to keep the questionnaire as simple as possible, we did not ask whether the agencies were multisectoral or sector specific. Some respondents volunteered this information but it was not sufficient to be able to have wide enough coverage. We expect to be able to generate this information from a follow-up questionnaire.

${ }^{4}$ Note that there is no normative assessment associated with the figures reported here.
} 
significantly across countries. On the regulatory agency, we realize that the information collected only reflects the existence of the regulatory agency but it does not capture the extent to which the agency is de facto independent.

The multiplicity of sources has allowed us to check the robustness of the information reported. Indeed, in most sectors, we identified inconsistencies across sources which needed to be investigated and corrected. This required significant efforts to contact officials in the countries and when that option was not available to contact desk officers in international agencies. In general, there was a lack of systematic formal interaction with the original sources which may be the main limitation of this database. Since at this stage we are quite confident about the emerging big picture, we have decided to disseminate a summary of the information collected so far while we continue our quality control. This means that this note should be followed up by updates and corrections.

The rest of this note presents the information collected on the two basic indicators for each sector in two main forms: (i) across income groups as per the standard World Bank indicators' classification ${ }^{5}$ and (ii) across geographical regions. The information collected on the first classification is generally much more robust than the second one because for some regions it was not possible to get large enough sample sizes (in particular for East Asia). The note covers electricity, water and sanitation, and telecoms. While we briefly discuss the main results of the survey for each sector, the main interest lies in the tables summarizing the information collected. In most cases, these tables speak for themselves. Note that in each table we have tried to be as clear as possible about sample sizes. Country specific data are provided in the appendix.

\section{Electricity}

For electricity, the main source of information was a questionnaire sent to task managers at the World Bank. However, this is the sector for which we benefited from the largest set of alternative sources of information A web search of all available publications and a reality check with a series of commercially available databases yielded relatively robust information ${ }^{6}$. We distinguished between electricity distribution and generation because we expected to get a different rate of private sector participation in these two segments of the business.

Tables 1 to 6 give an overview of the institutional changes that took place in the electricity sector during the 1990s according to the responses obtained. It provides a snapshot as of mid-2004 of the number of countries with "independent" regulatory

\footnotetext{
${ }^{5}$ Low income countries (LIC) are those in which 2001 GNI per capita was $\$ 745$ or less. Lower-middle income countries (LMC) are those in which $2001 \mathrm{GNI}$ per capita was between $\$ 745$ and $\$ 2,975$. Uppermiddle income countries (UMC) are those in which 2001 GNI per capita was between $\$ 2,976$ and $\$ 9,205$. High income countries are those in which 2001 GNI per capita was $\$ 9,206$ or more.

${ }^{6}$ See ABS Energy Research (2004), Bacon (1999), Estache and Gassner (2004a and 2004b), Henisz et. al. (2003), International Power Finance Review (2003-04), International Power and Utilities Finance Review (2004-05), Wallsten et. al. (2004), World Bank Caribbean Infrastructure Assessment (2004), and World Bank Global Energy Sector Reform (1999).
} 
agencies (tables 1 and 2), of the number of countries with private participation in generation (tables 3 and 4) and in distribution (tables 5 and 6). The sample size represents over $75 \%$ of the countries of the world, about $90 \%$ of the developing countries and $50 \%$ of developed countries. The results are thus quite robust for developing countries but may reflect a sample selection bias for developed countries.

Table 1 shows that in electricity the commitment to the creation of an independent regulator seems to increase with the income level. About $60 \%$ of the countries have created such an agency. This average is misleading and hides a major difference between developed and developing countries with corresponding scores of $92 \%$ and $50 \%$ respectively.

Table 1: Independent Electricity Regulatory Agency by Income Groups (2004)

\begin{tabular}{|lccc|}
\hline & $\begin{array}{c}\text { Universe } \\
\text { (\# of countries) }\end{array}$ & $\begin{array}{c}\text { Sample } \\
\text { (\# of countries } \\
\text { with data) }\end{array}$ & $\begin{array}{c}\text { Countries with IRA } \\
\text { (\% of sample) }\end{array}$ \\
\hline Developing countries & 155 & 136 & $51 \%$ \\
\hline Low income & 65 & 61 & $38 \%$ \\
\hline Lower-middle income & 52 & 43 & $63 \%$ \\
\hline Upper-middle income & 38 & 32 & $63 \%$ \\
\hline Developed countries (high income) & 52 & 29 & $79 \%$ \\
\hline \hline Total & 207 & 165 & $56 \%$ \\
\hline
\end{tabular}

Table 2 allows for an interesting refinement for developing economies. It shows that Latin America and Eastern Europe and Central Asia have actually been quite committed to the creation of these agencies while other developing regions have been much less committed, with the Middle East at the bottom of the list. It is interesting to note that the most committed regions have also engaged in additional activities of relevance to the effectiveness of reforms. Both Latin America and Eastern Europe have created regional associations of energy regulators, representing a step forward in benchmarking regional performances and hence generating data of the type used in this note.

Table 2: Independent Electricity Regulatory Agency by Regions (2004)

\begin{tabular}{|lccc|}
\hline & $\begin{array}{c}\text { Universe } \\
\text { (\# of countries) }\end{array}$ & $\begin{array}{c}\text { Sample } \\
\text { (\# of countries } \\
\text { with data) }\end{array}$ & $\begin{array}{c}\text { Countries with } \\
\text { IRA } \\
\text { (\% of sample) }\end{array}$ \\
\hline Sub-Saharan Africa & 48 & 44 & $36 \%$ \\
\hline East Asia \& Pacific & 22 & 11 & $36 \%$ \\
\hline Eastern Europe \& Central Asia & 28 & 27 & $78 \%$ \\
\hline Latin America \& Caribbean & 33 & 30 & $73 \%$ \\
\hline Middle East \& North Africa & 16 & 16 & $19 \%$ \\
\hline South Asia & 8 & 8 & $50 \%$ \\
\hline Rest of Countries & 52 & 29 & $79 \%$ \\
\hline \hline Total & 207 & 165 & $56 \%$ \\
\hline
\end{tabular}


Tables 3 and 4 show that roughly half of the countries around the world have private participation in electricity generation. Again, there is a significant difference between developing and developed countries and the shares seem to increase with income level. However, the difference between low and lower-middle income groups is less marked than the one for the creation of regulatory institutions. It is interesting to note that for developing regions there are 23 countries with regulatory agencies but without private participation in generation, and 15 countries with private participation but without an independent regulator.

Table 3: Private Participation in Electricity Generation by Income Groups (2004)

\begin{tabular}{|lccc|}
\hline & $\begin{array}{c}\text { Universe } \\
\text { (\# of countries) }\end{array}$ & $\begin{array}{c}\text { Sample } \\
\text { (\# of countries } \\
\text { with data) }\end{array}$ & $\begin{array}{c}\text { Countries with } \\
\text { Private Participation } \\
\text { in Generation } \\
\text { (\% of sample) }\end{array}$ \\
\hline Developing countries & 155 & 134 & $47 \%$ \\
\hline Low income & 65 & 59 & $41 \%$ \\
\hline Lower-middle income & 52 & 42 & $48 \%$ \\
\hline Upper-middle income & 38 & 33 & $58 \%$ \\
\hline Developed countries (high income) & 52 & 30 & $70 \%$ \\
\hline \hline Total & 207 & 164 & $51 \%$ \\
\hline
\end{tabular}

Table 4 once more refines the regional pictures but not as precisely as for the agencies. First, for one region, East Asia, the sample size is not large enough to be able to draw good lessons from the table. Second, there was some confusion from the information collected as to how large the private sector participation had to be to be accounted for. We left it to the interviewees to decide whether the presence was significant enough or not. This is clearly a subjective criterion which may not be acceptable to everyone.

Table 4: Private Participation in Electricity Generation by Regions (2004)

\begin{tabular}{|lccc|}
\hline & $\begin{array}{c}\text { Universe } \\
\text { (\# of countries) }\end{array}$ & $\begin{array}{c}\text { Sample } \\
\text { (\# of countries } \\
\text { with data) }\end{array}$ & $\begin{array}{c}\text { Countries with Private } \\
\text { Participation in Generation } \\
\text { (\% of sample) }\end{array}$ \\
\hline Sub-Saharan Africa & 48 & 46 & $41 \%$ \\
East Asia \& Pacific & 22 & 6 & $67 \%$ \\
\hline Eastern Europe \& Central Asia & 28 & 27 & $41 \%$ \\
Latin America \& Caribbean & 33 & 31 & $68 \%$ \\
\hline Middle East \& North Africa & 16 & 16 & $31 \%$ \\
South Asia & 8 & 8 & $38 \%$ \\
\hline Rest of Countries & 52 & 30 & $70 \%$ \\
\hline Total & 207 & 164 & $51 \%$ \\
\hline
\end{tabular}


Table 5 shows that the role of the private sector is lower in distribution than in generation. Less than $40 \%$ of the countries have any type of private financing of their electricity distribution. There is some difference again according to income groups within developing countries. About 3 in 10 countries of the bottom two income groups have private participation in distribution, while for the upper-middle income group approximately 5 in 10 have private participation. However, note that the presence of private participation in developed countries is not too different from the one in developing countries.

Table 5: Private Participation in Electricity Distribution by Income Groups (2004)

\begin{tabular}{|lccc|}
\hline & $\begin{array}{c}\text { Universe } \\
\text { (\# of countries) }\end{array}$ & $\begin{array}{c}\text { Sample } \\
\text { (\# of countries } \\
\text { with data) }\end{array}$ & $\begin{array}{c}\text { Countries with Private } \\
\text { Participation in } \\
\text { Distribution } \\
\text { (\% of sample) }\end{array}$ \\
\hline Developing countries & 155 & 138 & $36 \%$ \\
\hline Low income & 65 & 62 & $29 \%$ \\
\hline Lower-middle income & 52 & 43 & $37 \%$ \\
\hline Upper-middle income & 38 & 33 & $48 \%$ \\
\hline Developed countries (high income) & 52 & 21 & $43 \%$ \\
\hline \hline Total & 207 & 159 & $37 \%$ \\
\hline
\end{tabular}

Table 6 shows major differences across developing countries as well. The role of the private sector is significantly larger in Eastern Europe and Latin America than in any other part of the world with roughly 2 in 3 countries with private investment in distribution. This is more than the $43 \%$ share in developed countries. The Middle East and South Asia have been much less successful or interested in doing so (although it may be worth to point out that the sample size for East Asia and developed countries is not high enough to be able to draw generic conclusions on these two regions).

Table 6: Private Participation in Electricity Distribution by Regions (2004)

\begin{tabular}{|lccc|}
\hline & $\begin{array}{c}\text { Universe } \\
\text { (\# of countries) }\end{array}$ & $\begin{array}{c}\text { Sample } \\
\text { (\# of countries } \\
\text { with data) }\end{array}$ & $\begin{array}{c}\text { Countries with Private } \\
\text { Participation in } \\
\text { Distribution } \\
\text { (\% of sample) }\end{array}$ \\
\hline Sub-Saharan Africa & 48 & 46 & $28 \%$ \\
\hline East Asia \& Pacific & 22 & 10 & $20 \%$ \\
\hline Eastern Europe \& Central Asia & 28 & 27 & $48 \%$ \\
\hline Latin America \& Caribbean & 33 & 31 & $61 \%$ \\
\hline Middle East \& North Africa & 16 & 16 & $13 \%$ \\
\hline South Asia & 8 & 8 & $13 \%$ \\
\hline Rest of Countries & 52 & 21 & $43 \%$ \\
\hline \hline Total & 207 & 159 & $37 \%$ \\
\hline
\end{tabular}




\section{Water and sanitation}

For the water sector, the challenge in accounting for the existence of the private sector came with the large number of contractual forms that tend to prevail in the sector. Private capital was recorded when there are contracts that require capital investment by private parties in the sector. These contracts are: concessions, built-operate-transfer (BOT), and divestitures. On the other hand, service, management, affermage, and lease contracts were not classified as private capital ${ }^{7}$.

Tables 7 to 10 show that in this sector the information is less robust than for the others. We only have observations for about $66 \%$ of the countries of the world. Moreover the sample size is particularly small for developed countries. With these limitations in mind, the story that emerges is that significantly fewer countries have created independent regulators in the water sector than in electricity (or telecoms as discussed later). Less than $25 \%$ of the countries have an independent water utility regulator.

Table 7: Independent Water Regulatory Agency by Income Groups (2004)

\begin{tabular}{|lccc|}
\hline & $\begin{array}{c}\text { Universe } \\
\text { (\# of countries) }\end{array}$ & $\begin{array}{c}\text { Sample } \\
\text { (\# of countries } \\
\text { with data) }\end{array}$ & $\begin{array}{c}\text { Countries with IRA } \\
\text { (\% of sample) }\end{array}$ \\
\hline Developing countries & 155 & 122 & $21 \%$ \\
\hline Low income & 65 & 55 & $11 \%$ \\
\hline Lower-middle income & 52 & 38 & $32 \%$ \\
\hline Upper-middle income & 38 & 29 & $28 \%$ \\
\hline Developed countries (high income) & 52 & 15 & $20 \%$ \\
\hline \hline Total & 207 & 137 & $21 \%$ \\
\hline
\end{tabular}

Table 8 shows that Latin America is somewhat an upper bound outlier in the world since 1 in 2 countries in our large sample has created and agency. On the other hand, South Asia appears to be the lower bound outlier as no independent agency has been created in the region. The sample size for East Asia is not representative enough to be able to draw any lessons on this region. It is relevant to mention that the somewhat low commitment to the creation of independent water regulators might reflect the fact that the regulation of water utilities is part of the water resource management regulation, or that it is a decentralized matter at the municipal level, cases in which the creation of an independent regulator is seen as a costlier management model for the sector.

\footnotetext{
${ }^{7}$ Sources different from the questionnaire include: ABS Energy Research (2004), ADB Water in Asian Cities (2004), ADB Developing Best Practices for Promoting Private Sector Investment (2000), Bayliss (2002), Budds and McGranahan (2003), Estache and Gassner (2004a), Estache and Tracz (2004), Hall et. al. (2002a, 2002b, and 2002c), Lobina (2001), World Bank Sector Note on Water Supply (2004), World Bank Caribbean Infrastructure Assessment (2004), and World bank Water Supply and Sanitation and the MDGs (2003).
} 
Table 8: Independent Water Regulatory Agency by Regions (2004)

\begin{tabular}{|lccc|}
\hline & $\begin{array}{c}\text { Universe } \\
\text { (\# of countries) }\end{array}$ & $\begin{array}{c}\text { Sample } \\
\text { (\# of countries } \\
\text { with data) }\end{array}$ & $\begin{array}{c}\text { Countries with IRA } \\
\text { (\% of sample) }\end{array}$ \\
\hline Sub-Saharan Africa & 48 & 42 & $12 \%$ \\
\hline East Asia \& Pacific & 22 & 8 & $25 \%$ \\
\hline Eastern Europe \& Central Asia & 28 & 20 & $20 \%$ \\
\hline Latin America \& Caribbean & 33 & 30 & $50 \%$ \\
\hline Middle East \& North Africa & 16 & 14 & $0 \%$ \\
\hline South Asia & 8 & 8 & $0 \%$ \\
\hline Rest of Countries & 52 & 15 & $20 \%$ \\
\hline \hline Total & 207 & 137 & $21 \%$ \\
\hline
\end{tabular}

Tables 9 and 10 show that the private sector has a relatively strong presence in the delivery of water services of middle-income countries. Indeed, it is not unusual to find BOT deals in major cities to treat water. These opportunities are however more limited in low income countries, where management contracts tend to be much more common than contracts that require at least some private sector financing.

Table 9: Private Capital in Water and Sanitation by Income Groups (2004)

\begin{tabular}{|lccc|}
\hline & $\begin{array}{c}\text { Universe } \\
\text { (\# of countries) }\end{array}$ & $\begin{array}{c}\text { Sample } \\
\text { (\# of countries } \\
\text { with data) }\end{array}$ & $\begin{array}{c}\text { Countries with Private } \\
\text { Capital } \\
\text { (\% of sample) }\end{array}$ \\
\hline Developing countries & 155 & 127 & $35 \%$ \\
\hline Low income & 65 & 55 & $18 \%$ \\
\hline Lower-middle income & 52 & 40 & $50 \%$ \\
\hline Upper-middle income & 38 & 32 & $47 \%$ \\
\hline Developed countries (high income) & 52 & 20 & $80 \%$ \\
\hline \hline Total & 207 & 147 & $41 \%$ \\
\hline
\end{tabular}

Table 10 shows the strong variation across regions. Sub-Saharan Africa, the Middle East and South Asia, which include many of the poorest countries of the world, have had very little success in attracting private capital to the sector. In East Asia, there are only a few large concessions but many BOTs and service deals managed by international private companies, including very aggressive Asian companies who have managed to get a fair share of the deals in China and in Asia's “tiger countries". In contrast, for Latin America and Eastern Europe national private investment plays a very important role. Argentina, Brazil and Chile have enjoyed a reasonable collaboration of the international and national private capitals, and in Eastern Europe countries like the Czech Republic have developed a very active local private sector.

The diversity reflected in Table 10 also suggests that the ability to attract capital investment by private parties is driven by multiple factors and not only by income levels. In many countries, strategic decisions regarding water continue to be made at the local level, often municipal rather provincial or regional, allowing for a much wider variety of 
preferences and supply structures than in the energy sector. Commercial risk levels might however be quite important as reflected by the low attractiveness of Sub-Saharan Africa, South Asia and the Middle East.

Table 10: Private Capital in Water and Sanitation by Regions (2004)

\begin{tabular}{|lccc|}
\hline & $\begin{array}{c}\text { Universe } \\
\text { (\# of countries) }\end{array}$ & $\begin{array}{c}\text { Sample } \\
\text { (\# of countries } \\
\text { with data) }\end{array}$ & $\begin{array}{c}\text { Countries with } \\
\text { Private Capital } \\
\text { (\% of sample) }\end{array}$ \\
\hline Sub-Saharan Africa & 48 & 44 & $20 \%$ \\
\hline East Asia \& Pacific & 22 & 11 & $64 \%$ \\
\hline Eastern Europe \& Central Asia & 28 & 21 & $62 \%$ \\
\hline Latin America \& Caribbean & 33 & 29 & $41 \%$ \\
\hline Middle East \& North Africa & 16 & 14 & $21 \%$ \\
\hline South Asia & 8 & 8 & $13 \%$ \\
\hline Rest of Countries & 52 & 20 & $80 \%$ \\
\hline \hline Total & 207 & 147 & $41 \%$ \\
\hline
\end{tabular}

\section{Telecoms}

For the telecom sector, we have relied on an annual publication by the International Telecommunications Union (ITU) called "Trends in Telecommunication Reform" (latest data available for 2004) ${ }^{8}$. The report lists countries with an independent regulatory agency. After consulting with ITU and World Bank ICT experts, our classification assumes that countries that do not appear in the list do not to have an independent agency. This allows us to have a sample of 207 countries for this indicator.

Tables 11 and 12 suggest that this is the sector in which the commitment to institutional reform has been the strongest. Two out of three countries in the world have an independent telecom regulator. The developing countries have in fact a stronger commitment to this reform than developed countries. The lowest income groups are particularly impressive in that regard.

Table 11: Independent Telecom Regulatory Agency by Income Groups (2004)

\begin{tabular}{|lccc|}
\hline & $\begin{array}{c}\text { Universe } \\
\text { (\# of countries) }\end{array}$ & $\begin{array}{c}\text { Sample } \\
\text { (\# of countries } \\
\text { with data) }\end{array}$ & $\begin{array}{c}\text { Countries with IRA } \\
\text { (\% of sample) }\end{array}$ \\
\hline Developing countries & 155 & 155 & $66 \%$ \\
\hline Low income & 65 & 65 & $69 \%$ \\
\hline Lower-middle income & 52 & 52 & $60 \%$ \\
\hline Upper-middle income & 38 & 38 & $71 \%$ \\
\hline Developed countries (high income) & 52 & 52 & $56 \%$ \\
\hline \hline Total & 207 & 207 & $64 \%$ \\
\hline
\end{tabular}

\footnotetext{
${ }^{8}$ Other sources used to crosscheck data include: Henisz et. al. (2003), Wallsten et. al. (2004), World Bank Caribbean Infrastructure Assessment (2004), and Zhen-Wei Qiang (2004).
} 
Table 12 shows that the two poorest regions of the world, Sub-Saharan Africa and South Asia have been among the most committed to the creation of an independent regulator. Latin America is once again an outlier in its strong commitment to reform in comparison to other parts of the world. East Asia may be somewhat of a surprise in its modest commitment to reform since it appears that about 1 country in 4 has engaged in this specific institutional reform.

Table 12: Independent Telecom Regulatory Agency by Regions (2004)

\begin{tabular}{|lccc|}
\hline & $\begin{array}{c}\text { Universe } \\
\text { (\# of countries) }\end{array}$ & $\begin{array}{c}\text { Sample } \\
\text { (\# of countries } \\
\text { with data) }\end{array}$ & $\begin{array}{c}\text { Countries with IRA } \\
\text { (\% of sample) }\end{array}$ \\
\hline Sub-Saharan Africa & 48 & 48 & $77 \%$ \\
\hline East Asia \& Pacific & 22 & 22 & $27 \%$ \\
\hline Eastern Europe \& Central Asia & 28 & 28 & $57 \%$ \\
\hline Latin America \& Caribbean & 33 & 33 & $85 \%$ \\
\hline Middle East \& North Africa & 16 & 16 & $50 \%$ \\
\hline South Asia & 8 & 8 & $100 \%$ \\
\hline Rest of Countries & 52 & 52 & $56 \%$ \\
\hline \hline Total & 207 & 207 & $64 \%$ \\
\hline
\end{tabular}

Regarding private capital, we focus on the existence of private ownership in the local loop. Private capital is credited when the operators are partially or fully privatized (or equivalently when the operator is not state-owned). The story emerging from tables 13 and 14 is quite strong in showing that the commitment to the creation of an independent regulator is not a sufficient condition to attract private capital in the local loop. The presence of the private sector in the local loop of the lowest income groups is indeed much more limited than the commitment to regulatory reform. It turns out that for this group, corporatization of the operators is much more common than their privatization. Developed countries have had much fewer problems in attracting the private sector.

Table 13: Private Capital in Telecommunications by Income Groups (2004)

\begin{tabular}{|cccc|}
\hline & $\begin{array}{c}\text { Universe } \\
\text { (\# of countries) }\end{array}$ & $\begin{array}{c}\text { Sample } \\
\text { (\# of countries } \\
\text { with data) }\end{array}$ & $\begin{array}{c}\text { Countries with } \\
\text { Private Capital (\% of } \\
\text { sample) }\end{array}$ \\
\hline Developing countries & 155 & 146 & $59 \%$ \\
\hline Low income & 65 & 64 & $50 \%$ \\
\hline Lower-middle income & 52 & 50 & $62 \%$ \\
\hline Upper-middle income & 38 & 32 & $72 \%$ \\
\hline High income & 52 & 38 & $84 \%$ \\
\hline \hline Total & 207 & 184 & $64 \%$ \\
\hline
\end{tabular}


The regional distribution reinforces the impression that the ability to attract private capital is not strongly correlated with the commitments to the creation of independent regulators. Africa, for instance, has $77 \%$ of the countries with telecom regulators and only $51 \%$ with private participation in the local loop-note that the regulator deals with the interconnection issues of the very successful mobile telephony whether the fixed operators are public or private. In contrast, East Asia, Eastern Europe and Central Asia, and the developed countries are the groups in which the presence of private capital is larger than the presence of independent regulators.

Table 14: Private Capital in Telecommunications by Regions (2004)

\begin{tabular}{|lccc|}
\hline & $\begin{array}{c}\text { Universe } \\
\text { (\# of countries) }\end{array}$ & $\begin{array}{c}\text { Sample } \\
\text { (\# of countries } \\
\text { with data) }\end{array}$ & $\begin{array}{c}\text { Share of Countries } \\
\text { with Private } \\
\text { Participation }\end{array}$ \\
\hline Sub-Saharan Africa & 48 & 47 & $51 \%$ \\
\hline East Asia \& Pacific & 22 & 18 & $61 \%$ \\
\hline Eastern Europe \& Central Asia & 28 & 27 & $70 \%$ \\
\hline Latin America \& Caribbean & 33 & 31 & $74 \%$ \\
\hline Middle East \& North Africa & 16 & 15 & $33 \%$ \\
\hline South Asia & 8 & 8 & $50 \%$ \\
\hline Rest of countries(developed) & 52 & 38 & $84 \%$ \\
\hline \hline Total & 207 & 184 & $64 \%$ \\
\hline
\end{tabular}




\section{Conclusion}

The main ambition of the paper was to generate data on the actual importance across sectors of the implementation of the two major reforms of the 1990s: the creation of independent regulators, and privatization. While the data are far from perfect, they provide a reasonable sense of the state of infrastructure reform around the world along these two dimensions.

The main obvious conclusions to be drawn from the survey are the following:

- The strongest commitment to the creation of an independent regulatory capacity in the world is in the telecoms sector and the weakest one is in the water and sanitation sector, since respectively, $64 \%$ and $21 \%$ of the countries have introduced independent agencies. Electricity also seems to be strongly committed to the reform as $56 \%$ of the countries have created an "independent" energy regulator.

- The institutional commitment to independent regulation is stronger in developing countries than in developed countries in telecoms and water and sanitation; it is only in electricity that it is stronger in developed countries.

- Around the world, private participation to meet the sectors' financing needs is strongest in telecoms with $64 \%$ of the countries benefiting from some private financing in the local loop and it is the lowest in electricity distribution with $37 \%$.

- The ability to attract private investment across sectors is generally higher for developed countries than for developing countries. The biggest gap is observed in water and sanitation.

- Within developing countries, the shares of both regulatory agencies and private sector involvement tend to increase with income levels.

- Latin America and Eastern Europe \& Central Asia (ECA) are outliers among the regions as they have, almost systematically across sectors, the highest shares for both indicators (an exception is ECA in water). 


\section{Bibliography}

ABS Energy Research (2004), Electricity Deregulation Report: Global, London.

ABS Energy Research (2004), Water and Waste Utilities of the World, London.

Asian Development Bank (2004), Water in Asian Cities - Utilities Performance and Civil Society Views, Manila.

Asian Development Bank (2000), Developing Best Practices for Promoting Private Sector Investment in Infrastructure: Water Supply, Manila.

Bacon, Robert (1999), “A scorecard for Energy Reform in Developing Countries". Public Policy for the Private Sector, Note No. 175. The World Bank.

Bacon, Robert, and John Besant-Jones (2001), “Global Electric Power Reform, Privatization and Liberalization of the Electric Power Industry in developing Countries". Annual Reviews Energy and the Environment, 2001, 26:331-359.

Bayliss, Kate (2002), Water Privatization in SSA: Progress, problems and policy implications, Public Services International Research Unit (PSIRU).

Budds, Jessica, and Gordon McGranahan (2003), Privatization and the Provision of Urban Water and Sanitation in Africa, Asia, and Latin America. Human Settlements Discussion Paper Series.

Estache, Antonio, and Katharina Gassner (2004), Recent Economic Developments in Electricity and Water Services in ECA countries: Basic facts and emerging issues, Mimeo. The World Bank.

Estache, Antonio, and Katharina Gassner (2004), The Electricity Sector of Sub-Saharan Africa: basic facts and emerging issues, Mimeo. The World Bank, 2004.

Estache, Antonio, and Gaetane Tracz (2004), Recent Economic Developments in the Water and Sanitation Sectors of Selected Sub-Saharan Countries, Mimeo. The World Bank.

Hall, David, Kate Bayliss, and Emanuele Lobina (2002), Water Privatization in Africa, Public Services International Research Unit (PSIRU).

Hall, David, and Emanuele Lobina (2002), Water Privatization in Latin America, Public Services International Research Unit (PSIRU).

Hall, David, Emanuele Lobina, and Robin de la Motte (2002), Water Privatization and Restructuring in Central and Eastern Europe and NIS Countries, Public Services International Research Unit (PSIRU). 
Halpern, Jonathan. (2002), A Global Overview of Urban Water Supply and Sanitation Sector Reform: Water Sector Reform Scorecard, Mimeo. World Bank,

Henisz, Witold, Bennet Zelner and Mauro Guillén (2003), International Coercion, Emulation and Policy Diffusion: Market-Oriented Infrastructure Reforms, 19771999, Wharton School research paper.

International Power Finance Review 2003-2004. Euromoney Publications. London, 2003.

International Power and Utilities Finance Review 2004-2005. Euromoney Publications. London, 2004.

International Telecommunications Union (2004), Trends in Telecommunication Reform: Licensing in an Era of Convergence, Geneva, 2004.

Lobina, Emanuele (2001), Water Privatization and Restructuring in Central and Eastern Europe, Public Services International Research Unit (PSIRU).

Wallsten, Scott, George Clarke, Luke Haggarty, Rosario Kaneshiro, Roger Noll, Mary Shirley, Lixin Colin Xu (2004). "New Tools for Studying Network Industry Reforms in Developing Countries: The Telecommunications and Electricity Regulation Database.” Policy Research Working Paper No. 3286. The World Bank.

World Bank (2004), Sector Note on Water Supply and Sanitation for Infrastructure in East Asia and the Pacific, prepared by Castalia Strategic Advisors.

World Bank (2004), Caribbean Infrastructure Assessment. Report No. 29680.

World Bank (2003), Water Supply and Sanitation and the MDGs, DC2003-004/Add.3. Paper prepared for the Spring Meetings of the Development Committee, Washington DC.

World Bank (1999), Global Energy Sector Reform in Developing Countries: A Scorecard. Joint UNDP/World Bank Energy Sector Management Assistant Programme (ESMAP).

Zhen-Wei Qiang, Christine (2004), Regulatory Reform and Competition Policy: Evolution of Regulatory Framework, Mimeo. The World Bank. 
Appendix: Data by Country 
Table A15: Extent of Reforms in Electricity Sector as of 2004

\begin{tabular}{|c|c|c|c|c|c|}
\hline $\begin{array}{l}\text { Income } \\
\text { Level (1) }\end{array}$ & $\begin{array}{l}\text { Geographic } \\
\text { Region (2) }\end{array}$ & Country Name & $\begin{array}{l}\text { Have Independent Regulatory } \\
\text { Agency? (Yes/ No) }\end{array}$ & $\begin{array}{l}\text { Have Private Participation in } \\
\text { Generation? (Yes/No) }\end{array}$ & $\begin{array}{l}\text { Have Private Participation in } \\
\text { Distribution? (Yes/No) }\end{array}$ \\
\hline LIC & SAR & Afghanistan & No & No & No \\
\hline LMC & ECA & Albania & Yes & No & No \\
\hline LMC & MNA & Algeria & Yes & Yes & No \\
\hline UMC & EAP & American Samoa & & & \\
\hline NOC & OTH & Andorra & & & \\
\hline LIC & AFR & Angola & No & Yes & No \\
\hline UMC & LRC & Antigua and Barbuda & No & No & No \\
\hline UMC & LRC & Argentina & Yes & Yes & Yes \\
\hline LIC & ECA & Armenia & Yes & Yes & Yes \\
\hline $\mathrm{NOC}$ & OTH & Aruba & & & \\
\hline OEC & OTH & Australia & Yes & Yes & \\
\hline OEC & OTH & Austria & Yes & Yes & \\
\hline LIC & ECA & Azerbaijan & No & No & No \\
\hline $\mathrm{NOC}$ & OTH & Bahamas, The & & & \\
\hline NOC & OTH & Bahrain & No & No & \\
\hline LIC & SAR & Bangladesh & Yes & Yes & No \\
\hline UMC & LRC & Barbados & Yes & Yes & Yes \\
\hline LMC & ECA & Belarus & No & No & No \\
\hline OEC & OTH & Belgium & Yes & Yes & No \\
\hline LMC & LRC & Belize & & Yes & Yes \\
\hline LIC & AFR & Benin & No & No & No \\
\hline $\mathrm{NOC}$ & OTH & Bermuda & & Yes & \\
\hline LIC & SAR & Bhutan & No & No & No \\
\hline LMC & LRC & Bolivia & Yes & Yes & Yes \\
\hline LMC & ECA & Bosnia and Herzegovina & Yes & No & No \\
\hline UMC & AFR & Botswana & No & No & No \\
\hline UMC & LRC & Brazil & Yes & Yes & Yes \\
\hline NOC & OTH & Brunei & & & \\
\hline LMC & ECA & Bulgaria & Yes & No & No \\
\hline LIC & AFR & Burkina Faso & No & Yes & No \\
\hline LIC & AFR & Burundi & No & No & No \\
\hline LIC & EAP & Cambodia & Yes & & Yes \\
\hline LIC & AFR & Cameroon & Yes & Yes & Yes \\
\hline OEC & OTH & Canada & Yes & & \\
\hline LMC & AFR & Cape Verde & Yes & Yes & Yes \\
\hline NOC & OTH & Cayman Islands & & & \\
\hline LIC & AFR & Central African Republic & No & No & No \\
\hline LIC & AFR & Chad & No & Yes & No \\
\hline $\mathrm{NOC}$ & OTH & Channel Islands & & & \\
\hline UMC & LRC & Chile & Yes & Yes & Yes \\
\hline LMC & EAP & China & No & No & No \\
\hline LMC & LRC & Colombia & Yes & Yes & Yes \\
\hline LIC & AFR & Comoros & & Yes & Yes \\
\hline LIC & AFR & Congo, Dem. Rep. & No & No & No \\
\hline LIC & AFR & Congo, Rep. & No & No & No \\
\hline UMC & LRC & Costa Rica & Yes & Yes & No \\
\hline LIC & AFR & Cote d'Ivoire & Yes & Yes & Yes \\
\hline UMC & ECA & Croatia & Yes & No & No \\
\hline LMC & LRC & Cuba & No & No & No \\
\hline NOC & OTH & Cyprus & & No & No \\
\hline UMC & ECA & Czech Republic & Yes & Yes & Yes \\
\hline OEC & OTH & Denmark & Yes & Yes & Yes \\
\hline LMC & MNA & Djibouti & No & No & No \\
\hline UMC & LRC & Dominica & No & Yes & Yes \\
\hline LMC & LRC & Dominican Republic & Yes & Yes & Yes \\
\hline LMC & LRC & Ecuador & Yes & & \\
\hline LMC & MNA & Egypt, Arab Rep. & No & Yes & No \\
\hline LMC & LRC & El Salvador & Yes & & Yes \\
\hline LIC & AFR & Equatorial Guinea & No & No & No \\
\hline LIC & AFR & Eritrea & No & No & No \\
\hline UMC & ECA & Estonia & Yes & Yes & Yes \\
\hline LIC & AFR & Ethiopia & No & No & No \\
\hline NOC & OTH & Faeroe Islands & & & \\
\hline LMC & EAP & Fiji & & & \\
\hline OEC & $\mathrm{OTH}$ & Finland & Yes & & \\
\hline OEC & OTH & France & Yes & No & No \\
\hline $\mathrm{NOC}$ & OTH & French Polynesia & & & \\
\hline UMC & AFR & Gabon & No & Yes & Yes \\
\hline LIC & AFR & Gambia, The & No & Yes & No \\
\hline LIC & ECA & Georgia & Yes & Yes & Yes \\
\hline OEC & OTH & Germany & Yes & Yes & Yes \\
\hline LIC & AFR & Ghana & Yes & Yes & Yes \\
\hline OEC & OTH & Greece & Yes & Yes & No \\
\hline NOC & $\mathrm{OTH}$ & Greenland & & & \\
\hline
\end{tabular}


Table A15: Extent of Reforms in Electricity Sector as of 2004

\begin{tabular}{|c|c|c|c|c|c|}
\hline \begin{tabular}{|l} 
Income \\
Level (1)
\end{tabular} & $\begin{array}{l}\text { Geographic } \\
\text { Region (2) }\end{array}$ & Country Name & $\begin{array}{l}\text { Have Independent Regulatory } \\
\text { Agency? (Yes/ No) }\end{array}$ & $\begin{array}{c}\text { Have Private Participation in } \\
\text { Generation? (Yes/No) }\end{array}$ & $\begin{array}{l}\text { Have Private Participation in } \\
\text { Distribution? (Yes/No) }\end{array}$ \\
\hline UMC & LRC & Grenada & No & Yes & Yes \\
\hline NOC & OTH & Guam & & & \\
\hline LMC & LRC & Guatemala & Yes & Yes & Yes \\
\hline LIC & AFR & Guinea & & Yes & Yes \\
\hline LIC & AFR & Guinea-Bissau & No & No & No \\
\hline LMC & LRC & Guyana & Yes & Yes & Yes \\
\hline LIC & LRC & Haiti & No & No & No \\
\hline LMC & LRC & Honduras & Yes & No & No \\
\hline $\mathrm{NOC}$ & $\mathrm{OTH}$ & Hong Kong, China & & Yes & \\
\hline UMC & ECA & Hungary & Yes & Yes & Yes \\
\hline OEC & OTH & Iceland & & No & No \\
\hline LIC & SAR & India & Yes & Yes & Yes \\
\hline LIC & EAP & Indonesia & No & Yes & No \\
\hline LMC & MNA & Iran, Islamic Rep. & No & No & No \\
\hline LMC & MNA & Iraq & No & No & No \\
\hline OEC & $\mathrm{OTH}$ & Ireland & Yes & & \\
\hline UMC & ECA & Isle of Man & & & \\
\hline $\mathrm{NOC}$ & OTH & Israel & Yes & No & No \\
\hline OEC & OTH & Italy & Yes & Yes & Yes \\
\hline LMC & LRC & Jamaica & Yes & Yes & Yes \\
\hline OEC & $\mathrm{OTH}$ & Japan & & Yes & \\
\hline LMC & MNA & Jordan & Yes & No & Yes \\
\hline LMC & ECA & Kazakhstan & Yes & Yes & No \\
\hline LIC & AFR & Kenya & Yes & Yes & No \\
\hline LMC & EAP & Kiribati & & & \\
\hline LIC & EAP & Korea, Dem. Rep. & No & Yes & No \\
\hline OEC & OTH & Korea, Rep. & No & No & No \\
\hline NOC & OTH & Kuwait & No & No & No \\
\hline LIC & ECA & Kyrgyz Republic & Yes & No & No \\
\hline LIC & EAP & Lao PDR & No & & No \\
\hline UMC & ECA & Latvia & Yes & No & No \\
\hline UMC & MNA & Lebanon & No & No & No \\
\hline LIC & AFR & Lesotho & No & No & No \\
\hline LIC & AFR & Liberia & No & No & No \\
\hline UMC & MNA & Libya & No & No & No \\
\hline $\mathrm{NOC}$ & OTH & Liechtenstein & & & \\
\hline UMC & ECA & Lithuania & Yes & Yes & Yes \\
\hline OEC & OTH & Luxembourg & Yes & Yes & Yes \\
\hline $\mathrm{NOC}$ & OTH & Macao, China & & & \\
\hline LMC & ECA & Macedonia, FYR & Yes & No & No \\
\hline LIC & AFR & Madagascar & No & No & No \\
\hline LIC & AFR & Malawi & No & No & No \\
\hline UMC & EAP & Malaysia & Yes & Yes & No \\
\hline LMC & SAR & Maldives & No & No & No \\
\hline LIC & AFR & Mali & Yes & Yes & Yes \\
\hline UMC & MNA & Malta & Yes & No & No \\
\hline LMC & EAP & Marshall Islands & & & \\
\hline LIC & AFR & Mauritania & Yes & No & No \\
\hline UMC & AFR & Mauritius & No & Yes & No \\
\hline UMC & AFR & Mayotte & & & \\
\hline UMC & LRC & Mexico & Yes & No & No \\
\hline LMC & EAP & Micronesia, Fed. Sts. & & & \\
\hline LIC & $\mathrm{ECA}$ & Moldova & Yes & No & Yes \\
\hline $\mathrm{NOC}$ & $\mathrm{OTH}$ & Monaco & & & \\
\hline LIC & EAP & Mongolia & Yes & & No \\
\hline LMC & MNA & Morocco & No & Yes & Yes \\
\hline LIC & AFR & Mozambique & Yes & Yes & Yes \\
\hline LIC & EAP & Myanmar & No & & \\
\hline LMC & AFR & Namibia & Yes & No & No \\
\hline LIC & SAR & Nepal & No & No & No \\
\hline OEC & $\mathrm{OTH}$ & Netherlands & Yes & Yes & Yes \\
\hline $\mathrm{NOC}$ & $\mathrm{OTH}$ & Netherlands Antilles & & & \\
\hline NOC & OTH & New Caledonia & & & \\
\hline OEC & OTH & New Zealand & Yes & Yes & \\
\hline LIC & LRC & Nicaragua & Yes & Yes & Yes \\
\hline LIC & AFR & Niger & Yes & No & No \\
\hline LIC & AFR & Nigeria & Yes & Yes & No \\
\hline $\mathrm{NOC}$ & $\mathrm{OTH}$ & Northern Mariana Islands & & & \\
\hline OEC & OTH & Norway & Yes & Yes & No \\
\hline UMC & MNA & Oman & No & No & No \\
\hline LIC & SAR & Pakistan & Yes & No & No \\
\hline UMC & EAP & Palau & & & \\
\hline UMC & LRC & Panama & Yes & Yes & Yes \\
\hline LIC & EAP & Papua New Guinea & & & \\
\hline LMC & LRC & Paraguay & Yes & No & No \\
\hline LMC & LRC & Peru & Yes & Yes & Yes \\
\hline
\end{tabular}


Table A15: Extent of Reforms in Electricity Sector as of 2004

\begin{tabular}{|c|c|c|c|c|c|}
\hline \begin{tabular}{|l|} 
Income \\
Level (1) \\
\end{tabular} & $\begin{array}{l}\text { Geographic } \\
\text { Region (2) }\end{array}$ & Country Name & $\begin{array}{l}\text { Have Independent Regulatory } \\
\text { Agency? (Yes/ No) }\end{array}$ & $\begin{array}{l}\text { Have Private Participation in } \\
\text { Generation? (Yes/No) }\end{array}$ & $\begin{array}{l}\text { Have Private Participation in } \\
\text { Distribution? (Yes/No) }\end{array}$ \\
\hline LMC & EAP & Philippines & Yes & & Yes \\
\hline UMC & ECA & Poland & Yes & Yes & Yes \\
\hline OEC & OTH & Portugal & Yes & Yes & Yes \\
\hline UMC & LRC & Puerto Rico & & No & No \\
\hline NOC & OTH & Qatar & No & Yes & \\
\hline LMC & ECA & Romania & Yes & No & Yes \\
\hline LMC & ECA & Russian Federation & Yes & Yes & Yes \\
\hline LIC & AFR & Rwanda & Yes & No & No \\
\hline LMC & EAP & Samoa & & & \\
\hline NOC & OTH & San Marino & & & \\
\hline LIC & AFR & Sao Tome and Principe & No & No & No \\
\hline UMC & MNA & Saudi Arabia & No & No & No \\
\hline LIC & AFR & Senegal & Yes & Yes & Yes \\
\hline UMC & AFR & Seychelles & & & \\
\hline LIC & AFR & Sierra Leone & No & No & No \\
\hline NOC & OTH & Singapore & Yes & & \\
\hline UMC & ECA & Slovak Republic & Yes & No & Yes \\
\hline NOC & OTH & Slovenia & Yes & No & No \\
\hline LIC & EAP & Solomon Islands & & & \\
\hline LIC & AFR & Somalia & No & No & No \\
\hline LMC & AFR & South Africa & Yes & No & No \\
\hline OEC & OTH & Spain & Yes & Yes & No \\
\hline LMC & SAR & Sri Lanka & Yes & Yes & No \\
\hline UMC & LRC & St. Kitts and Nevis & No & No & No \\
\hline UMC & LRC & St. Lucia & No & Yes & Yes \\
\hline LMC & LRC & St. Vincent and the Grenadines & No & No & No \\
\hline LIC & AFR & Sudan & No & No & No \\
\hline LMC & LRC & Suriname & & Yes & \\
\hline LMC & AFR & Swaziland & Yes & No & No \\
\hline OEC & OTH & Sweden & Yes & Yes & Yes \\
\hline OEC & OTH & Switzerland & No & & \\
\hline LMC & MNA & Syrian Arab Republic & No & No & No \\
\hline LIC & ECA & Tajikistan & No & No & No \\
\hline LIC & AFR & Tanzania & No & No & No \\
\hline LMC & EAP & Thailand & No & Yes & No \\
\hline LIC & AFR & Togo & Yes & Yes & Yes \\
\hline LMC & EAP & Tonga & & & \\
\hline UMC & LRC & Trinidad and Tobago & Yes & Yes & No \\
\hline LMC & MNA & Tunisia & No & Yes & No \\
\hline LMC & ECA & Turkey & Yes & Yes & Yes \\
\hline LMC & ECA & Turkmenistan & No & No & No \\
\hline LIC & AFR & Uganda & Yes & Yes & Yes \\
\hline LIC & ECA & Ukraine & Yes & Yes & Yes \\
\hline $\mathrm{NOC}$ & OTH & United Arab Emirates & No & Yes & \\
\hline OEC & OTH & United Kingdom & Yes & Yes & Yes \\
\hline OEC & OTH & United States & Yes & Yes & Yes \\
\hline UMC & LRC & Uruguay & Yes & No & No \\
\hline LIC & ECA & Uzbekistan & No & No & No \\
\hline LMC & EAP & Vanuatu & & & \\
\hline UMC & LRC & Venezuela, RB & Yes & Yes & Yes \\
\hline LIC & EAP & Vietnam & No & No & No \\
\hline NOC & OTH & Virgin Islands (U.S.) & & No & No \\
\hline LMC & MNA & West Bank and Gaza & No & Yes & No \\
\hline LIC & MNA & Yemen, Rep. & No & No & No \\
\hline LMC & ECA & Yugoslavia, FR (Serbia/Montenegro) & No & No & No \\
\hline LIC & AFR & Zambia & Yes & No & Yes \\
\hline LIC & AFR & Zimbabwe & No & No & No \\
\hline
\end{tabular}


Table A2: Extent of Reforms in Water Sector as of 2004

\begin{tabular}{|c|c|c|c|c|}
\hline \begin{tabular}{|l|} 
Income \\
Level (1)
\end{tabular} & $\begin{array}{l}\text { Geographic } \\
\text { Region (2) }\end{array}$ & Country Name & Have Independent Regulatory Agency? (Yes/ No) & Have Private Participation? (Yes/No) \\
\hline LIC & SAR & Afghanistan & No & No \\
\hline LMC & ECA & Albania & Yes & Yes \\
\hline LMC & MNA & Algeria & No & Yes \\
\hline UMC & EAP & American Samoa & & \\
\hline NOC & OTH & Andorra & & \\
\hline LIC & AFR & Angola & No & No \\
\hline UMC & LRC & Antigua and Barbuda & No & No \\
\hline UMC & LRC & Argentina & Yes & Yes \\
\hline LIC & ECA & Armenia & No & No \\
\hline NOC & OTH & Aruba & & \\
\hline OEC & OTH & Australia & & Yes \\
\hline OEC & OTH & Austria & No & Yes \\
\hline LIC & ECA & Azerbaijan & No & No \\
\hline NOC & OTH & Bahamas, The & & \\
\hline NOC & OTH & Bahrain & & \\
\hline LIC & SAR & Bangladesh & No & No \\
\hline UMC & LRC & Barbados & Yes & No \\
\hline LMC & ECA & Belarus & No & \\
\hline OEC & OTH & Belgium & & Yes \\
\hline LMC & LRC & Belize & Yes & \\
\hline LIC & AFR & Benin & No & No \\
\hline NOC & OTH & Bermuda & & \\
\hline LIC & SAR & Bhutan & No & No \\
\hline LMC & LRC & Bolivia & Yes & Yes \\
\hline LMC & ECA & Bosnia and Herzegovina & Yes & \\
\hline UMC & AFR & Botswana & No & No \\
\hline UMC & LRC & Brazil & No & Yes \\
\hline NOC & OTH & Brunei & & \\
\hline LMC & ECA & Bulgaria & No & Yes \\
\hline LIC & AFR & Burkina Faso & No & No \\
\hline LIC & AFR & Burundi & No & No \\
\hline LIC & EAP & Cambodia & No & Yes \\
\hline LIC & AFR & Cameroon & No & Yes \\
\hline OEC & OTH & Canada & & \\
\hline LMC & AFR & Cape Verde & Yes & Yes \\
\hline NOC & OTH & Cayman Islands & & \\
\hline LIC & AFR & Central African Republic & No & No \\
\hline LIC & AFR & Chad & No & No \\
\hline NOC & OTH & Channel Islands & & \\
\hline UMC & LRC & Chile & Yes & Yes \\
\hline LMC & EAP & China & & Yes \\
\hline LMC & LRC & Colombia & Yes & Yes \\
\hline LIC & AFR & Comoros & & \\
\hline LIC & AFR & Congo, Dem. Rep. & No & No \\
\hline LIC & AFR & Congo, Rep. & No & Yes \\
\hline UMC & LRC & Costa Rica & Yes & No \\
\hline LIC & AFR & Cote d'Ivoire & No & Yes \\
\hline UMC & ECA & Croatia & Yes & Yes \\
\hline LMC & LRC & Cuba & & Yes \\
\hline NOC & OTH & Cyprus & No & No \\
\hline UMC & ECA & Czech Republic & & Yes \\
\hline OEC & OTH & Denmark & No & No \\
\hline LMC & MNA & Djibouti & No & \\
\hline UMC & LRC & Dominica & No & Yes \\
\hline LMC & LRC & Dominican Republic & No & No \\
\hline LMC & LRC & Ecuador & No & Yes \\
\hline LMC & MNA & Egypt, Arab Rep. & No & No \\
\hline LMC & LRC & El Salvador & No & No \\
\hline LIC & AFR & Equatorial Guinea & No & No \\
\hline LIC & AFR & Eritrea & No & No \\
\hline UMC & ECA & Estonia & No & Yes \\
\hline LIC & AFR & Ethiopia & No & No \\
\hline NOC & OTH & Faeroe Islands & & \\
\hline LMC & EAP & Fiji & & \\
\hline OEC & OTH & Finland & No & Yes \\
\hline OEC & OTH & France & No & Yes \\
\hline NOC & OTH & French Polynesia & & \\
\hline UMC & AFR & Gabon & No & Yes \\
\hline LIC & AFR & Gambia, The & No & No \\
\hline LIC & ECA & Georgia & No & No \\
\hline OEC & OTH & Germany & No & Yes \\
\hline LIC & AFR & Ghana & Yes & No \\
\hline OEC & OTH & Greece & No & Yes \\
\hline NOC & OTH & Greenland & & \\
\hline UMC & LRC & Grenada & No & No \\
\hline
\end{tabular}


Table A2: Extent of Reforms in Water Sector as of 2004

\begin{tabular}{|c|c|c|c|c|}
\hline $\begin{array}{l}\text { Income } \\
\text { Level (1) }\end{array}$ & $\begin{array}{l}\text { Geographic } \\
\text { Region (2) }\end{array}$ & Country Name & Have Independent Regulatory Agency? (Yes/ No) & Have Private Participation? (Yes/No) \\
\hline NOC & $\mathrm{OTH}$ & Guam & & \\
\hline LMC & LRC & Guatemala & No & No \\
\hline LIC & AFR & Guinea & No & No \\
\hline LIC & AFR & Guinea-Bissau & No & No \\
\hline LMC & LRC & Guyana & No & Yes \\
\hline LIC & LRC & Haiti & No & \\
\hline LMC & LRC & Honduras & Yes & Yes \\
\hline NOC & $\mathrm{OTH}$ & Hong Kong, China & & No \\
\hline UMC & ECA & Hungary & No & Yes \\
\hline OEC & OTH & Iceland & No & \\
\hline LIC & SAR & India & No & Yes \\
\hline LIC & EAP & Indonesia & No & Yes \\
\hline LMC & MNA & Iran, Islamic Rep. & No & No \\
\hline LMC & MNA & Iraq & No & No \\
\hline OEC & OTH & Ireland & No & Yes \\
\hline UMC & ECA & Isle of Man & & \\
\hline NOC & OTH & Israel & & \\
\hline OEC & OTH & Italy & Yes & Yes \\
\hline LMC & LRC & Jamaica & Yes & No \\
\hline OEC & OTH & Japan & & \\
\hline LMC & MNA & Jordan & No & No \\
\hline LMC & ECA & Kazakhstan & No & Yes \\
\hline LIC & AFR & Kenya & No & No \\
\hline LMC & EAP & Kiribati & & \\
\hline LIC & EAP & Korea, Dem. Rep. & & \\
\hline OEC & OTH & Korea, Rep. & & \\
\hline NOC & OTH & Kuwait & & \\
\hline LIC & ECA & Kyrgyz Republic & No & \\
\hline LIC & EAP & Lao PDR & Yes & No \\
\hline UMC & ECA & Latvia & No & No \\
\hline UMC & MNA & Lebanon & No & No \\
\hline LIC & AFR & Lesotho & No & No \\
\hline LIC & AFR & Liberia & No & No \\
\hline UMC & MNA & Libya & & No \\
\hline NOC & OTH & Liechtenstein & & \\
\hline UMC & ECA & Lithuania & No & No \\
\hline OEC & $\mathrm{OTH}$ & Luxembourg & No & \\
\hline NOC & $\mathrm{OTH}$ & Macao, China & & \\
\hline LMC & ECA & Macedonia, FYR & & No \\
\hline LIC & AFR & Madagascar & & No \\
\hline LIC & AFR & Malawi & No & No \\
\hline UMC & EAP & Malaysia & No & Yes \\
\hline LMC & SAR & Maldives & No & No \\
\hline LIC & AFR & Mali & Yes & Yes \\
\hline UMC & MNA & Malta & No & \\
\hline LMC & EAP & Marshall Islands & & \\
\hline LIC & AFR & Mauritania & No & No \\
\hline UMC & AFR & Mauritius & & No \\
\hline UMC & AFR & Mayotte & & \\
\hline UMC & LRC & Mexico & Yes & Yes \\
\hline LMC & EAP & Micronesia, Fed. Sts. & & \\
\hline LIC & ECA & Moldova & & \\
\hline NOC & $\mathrm{OTH}$ & Monaco & & \\
\hline LIC & EAP & Mongolia & & No \\
\hline LMC & MNA & Morocco & No & Yes \\
\hline LIC & AFR & Mozambique & Yes & Yes \\
\hline LIC & EAP & Myanmar & & \\
\hline LMC & AFR & Namibia & No & No \\
\hline LIC & SAR & Nepal & No & No \\
\hline OEC & OTH & Netherlands & No & Yes \\
\hline NOC & OTH & Netherlands Antilles & & \\
\hline NOC & OTH & New Caledonia & & \\
\hline OEC & OTH & New Zealand & & Yes \\
\hline LIC & LRC & Nicaragua & Yes & No \\
\hline LIC & AFR & Niger & Yes & Yes \\
\hline LIC & AFR & Nigeria & No & No \\
\hline NOC & OTH & Northern Mariana Islands & & \\
\hline OEC & OTH & Norway & & \\
\hline UMC & MNA & Oman & & No \\
\hline LIC & SAR & Pakistan & No & No \\
\hline UMC & EAP & Palau & No & No \\
\hline UMC & LRC & Panama & Yes & No \\
\hline LIC & EAP & Papua New Guinea & No & No \\
\hline LMC & LRC & Paraguay & Yes & No \\
\hline LMC & LRC & Peru & Yes & No \\
\hline LMC & EAP & Philippines & Yes & Yes \\
\hline
\end{tabular}


Table A2: Extent of Reforms in Water Sector as of 2004

\begin{tabular}{|c|c|c|c|c|}
\hline \begin{tabular}{|l} 
Income \\
Level (1)
\end{tabular} & $\begin{array}{l}\text { Geographic } \\
\text { Region (2) }\end{array}$ & Country Name & Have Independent Regulatory Agency? (Yes/ No) & Have Private Participation? (Yes/No) \\
\hline UMC & ECA & Poland & No & Yes \\
\hline OEC & OTH & Portugal & & Yes \\
\hline UMC & LRC & Puerto Rico & & \\
\hline NOC & OTH & Qatar & & Yes \\
\hline LMC & ECA & Romania & Yes & Yes \\
\hline LMC & ECA & Russian Federation & & Yes \\
\hline LIC & AFR & Rwanda & No & No \\
\hline LMC & EAP & Samoa & & \\
\hline NOC & OTH & San Marino & & \\
\hline LIC & AFR & Sao Tome and Principe & No & No \\
\hline UMC & MNA & Saudi Arabia & No & Yes \\
\hline LIC & AFR & Senegal & No & No \\
\hline UMC & AFR & Seychelles & & \\
\hline LIC & AFR & Sierra Leone & No & No \\
\hline NOC & OTH & Singapore & & No \\
\hline UMC & ECA & Slovak Republic & No & Yes \\
\hline NOC & OTH & Slovenia & No & Yes \\
\hline LIC & EAP & Solomon Islands & & \\
\hline LIC & AFR & Somalia & & \\
\hline LMC & AFR & South Africa & No & Yes \\
\hline OEC & OTH & Spain & Yes & Yes \\
\hline LMC & SAR & Sri Lanka & No & No \\
\hline UMC & LRC & St. Kitts and Nevis & No & No \\
\hline UMC & LRC & St. Lucia & No & No \\
\hline LMC & LRC & $\begin{array}{l}\text { St. Vincent and the } \\
\text { Grenadines }\end{array}$ & No & No \\
\hline LIC & AFR & Sudan & No & No \\
\hline LMC & LRC & Suriname & & \\
\hline LMC & AFR & Swaziland & No & No \\
\hline OEC & OTH & Sweden & No & \\
\hline OEC & OTH & Switzerland & & \\
\hline LMC & MNA & Syrian Arab Republic & No & No \\
\hline LIC & ECA & Tajikistan & No & No \\
\hline LIC & AFR & Tanzania & No & No \\
\hline LMC & EAP & Thailand & & Yes \\
\hline LIC & AFR & Togo & No & No \\
\hline LMC & EAP & Tonga & & \\
\hline UMC & LRC & Trinidad and Tobago & No & No \\
\hline LMC & MNA & Tunisia & No & No \\
\hline LMC & ECA & Turkey & & Yes \\
\hline LMC & ECA & Turkmenistan & No & No \\
\hline LIC & AFR & Uganda & No & No \\
\hline LIC & ECA & Ukraine & & \\
\hline NOC & OTH & United Arab Emirates & & \\
\hline OEC & OTH & United Kingdom & Yes & Yes \\
\hline OEC & OTH & United States & & Yes \\
\hline UMC & LRC & Uruguay & Yes & Yes \\
\hline LIC & ECA & Uzbekistan & & \\
\hline LMC & EAP & Vanuatu & & \\
\hline UMC & LRC & Venezuela, RB & No & No \\
\hline LIC & EAP & Vietnam & No & Yes \\
\hline $\mathrm{NOC}$ & OTH & Virgin Islands (U.S.) & & \\
\hline LMC & MNA & West Bankand Gaza & No & No \\
\hline LIC & MNA & Yemen, Rep. & No & No \\
\hline LMC & ECA & $\begin{array}{l}\text { Yugoslavia, FR } \\
\text { (Serbia/Montenegro) }\end{array}$ & No & Yes \\
\hline LIC & AFR & Zambia & Yes & No \\
\hline LIC & AFR & Zimbabwe & No & No \\
\hline
\end{tabular}


Table A3: Extent of Reforms in ICT Sector as of 2004

\begin{tabular}{|c|c|c|c|c|}
\hline \begin{tabular}{|l|} 
Income \\
Level (1)
\end{tabular} & $\begin{array}{l}\text { Geographic } \\
\text { Region (2) }\end{array}$ & Country Name & Have Independent Regulatory Agency? (Yes/ No) & Have Private Participation? (Yes/No) \\
\hline LIC & SAR & Afghanistan & Yes & No \\
\hline LMC & $\mathrm{ECA}$ & Albania & Yes & No \\
\hline LMC & MNA & Algeria & Yes & No \\
\hline UMC & EAP & American Samoa & No & \\
\hline $\mathrm{NOC}$ & OTH & Andorra & No & No \\
\hline LIC & AFR & Angola & Yes & Yes \\
\hline UMC & LRC & Antigua and Barbuda & No & No \\
\hline UMC & LRC & Argentina & Yes & Yes \\
\hline LIC & ECA & Armenia & No & Yes \\
\hline NOC & OTH & Aruba & No & \\
\hline OEC & OTH & Australia & Yes & Yes \\
\hline OEC & OTH & Austria & Yes & Yes \\
\hline LIC & ECA & Azerbaijan & No & No \\
\hline NOC & OTH & Bahamas, The & Yes & No \\
\hline NOC & OTH & Bahrain & Yes & Yes \\
\hline LIC & SAR & Bangladesh & Yes & No \\
\hline UMC & LRC & Barbados & Yes & Yes \\
\hline LMC & ECA & Belarus & No & No \\
\hline OEC & OTH & Belgium & Yes & Yes \\
\hline LMC & LRC & Belize & Yes & Yes \\
\hline LIC & AFR & Benin & Yes & No \\
\hline NOC & OTH & Bermuda & No & \\
\hline LIC & SAR & Bhutan & Yes & No \\
\hline LMC & LRC & Bolivia & Yes & Yes \\
\hline LMC & ECA & Bosnia and Herzegovina & Yes & Yes \\
\hline UMC & AFR & Botswana & Yes & No \\
\hline UMC & LRC & Brazil & Yes & Yes \\
\hline NOC & OTH & Brunei & Yes & No \\
\hline LMC & $\mathrm{ECA}$ & Bulgaria & Yes & Yes \\
\hline LIC & AFR & Burkina Faso & Yes & No \\
\hline LIC & AFR & Burundi & Yes & No \\
\hline LIC & EAP & Cambodia & No & No \\
\hline LIC & AFR & Cameroon & Yes & No \\
\hline OEC & OTH & Canada & Yes & Yes \\
\hline LMC & AFR & Cape Verde & Yes & Yes \\
\hline NOC & OTH & Cayman Islands & No & \\
\hline LIC & AFR & Central African Republic & Yes & Yes \\
\hline LIC & AFR & Chad & Yes & No \\
\hline NOC & OTH & Channel Islands & No & \\
\hline UMC & LRC & Chile & Yes & Yes \\
\hline LMC & EAP & China & No & Yes \\
\hline LMC & LRC & Colombia & Yes & Yes \\
\hline LIC & AFR & Comoros & No & No \\
\hline LIC & AFR & Congo, Dem. Rep. & Yes & No \\
\hline LIC & AFR & Congo, Rep. & No & No \\
\hline UMC & LRC & Costa Rica & Yes & No \\
\hline LIC & AFR & Cote d'Ivoire & Yes & Yes \\
\hline UMC & ECA & Croatia & Yes & Yes \\
\hline LMC & LRC & Cuba & No & Yes \\
\hline NOC & OTH & Cyprus & Yes & No \\
\hline UMC & ECA & Czech Republic & Yes & Yes \\
\hline OEC & OTH & Denmark & Yes & Yes \\
\hline LMC & MNA & Djibouti & No & No \\
\hline UMC & LRC & Dominica & No & Yes \\
\hline LMC & LRC & Dominican Republic & Yes & Yes \\
\hline LMC & LRC & Ecuador & Yes & No \\
\hline LMC & MNA & Egypt, Arab Rep. & Yes & No \\
\hline LMC & LRC & EI Salvador & Yes & Yes \\
\hline LIC & AFR & Equatorial Guinea & No & Yes \\
\hline LIC & AFR & Eritrea & Yes & No \\
\hline UMC & ECA & Estonia & Yes & Yes \\
\hline LIC & AFR & Ethiopia & Yes & No \\
\hline NOC & OTH & Faeroe Islands & No & \\
\hline LMC & EAP & Fiji & No & Yes \\
\hline OEC & OTH & Finland & Yes & Yes \\
\hline OEC & OTH & France & Yes & Yes \\
\hline NOC & OTH & French Polynesia & No & \\
\hline UMC & AFR & Gabon & Yes & No \\
\hline LIC & AFR & Gambia, The & Yes & No \\
\hline LIC & ECA & Georgia & Yes & Yes \\
\hline OEC & OTH & Germany & Yes & Yes \\
\hline LIC & AFR & Ghana & Yes & Yes \\
\hline OEC & OTH & Greece & Yes & Yes \\
\hline
\end{tabular}


Table A3: Extent of Reforms in ICT Sector as of 2004

\begin{tabular}{|c|c|c|c|c|}
\hline \begin{tabular}{|l} 
Income \\
Level (1)
\end{tabular} & $\begin{array}{l}\text { Geographic } \\
\text { Region (2) }\end{array}$ & Country Name & Have Independent Regulatory Agency? (Yes/ No) & Have Private Participation? (Yes/No) \\
\hline NOC & OTH & Greenland & No & \\
\hline UMC & LRC & Grenada & Yes & Yes \\
\hline NOC & $\mathrm{OTH}$ & Guam & No & \\
\hline LMC & LRC & Guatemala & Yes & Yes \\
\hline LIC & AFR & Guinea & Yes & Yes \\
\hline LIC & AFR & Guinea-Bissau & Yes & Yes \\
\hline LMC & LRC & Guyana & Yes & Yes \\
\hline LIC & LRC & Haiti & Yes & Yes \\
\hline LMC & LRC & Honduras & Yes & No \\
\hline $\mathrm{NOC}$ & $\mathrm{OTH}$ & Hong Kong, China & No & \\
\hline UMC & ECA & Hungary & Yes & Yes \\
\hline OEC & OTH & Iceland & Yes & Yes \\
\hline LIC & SAR & India & Yes & Yes \\
\hline LIC & EAP & Indonesia & Yes & Yes \\
\hline LMC & MNA & Iran, Islamic Rep. & No & Yes \\
\hline LMC & MNA & Iraq & No & No \\
\hline OEC & OTH & Ireland & Yes & Yes \\
\hline UMC & ECA & Isle of Man & No & \\
\hline NOC & OTH & Israel & No & Yes \\
\hline OEC & $\mathrm{OTH}$ & Italy & Yes & Yes \\
\hline LMC & LRC & Jamaica & Yes & Yes \\
\hline OEC & $\mathrm{OTH}$ & Japan & No & Yes \\
\hline LMC & MNA & Jordan & Yes & Yes \\
\hline LMC & ECA & Kazakhstan & No & Yes \\
\hline LIC & AFR & Kenya & Yes & No \\
\hline LMC & EAP & Kiribati & No & Yes \\
\hline LIC & EAP & Korea, Dem. Rep. & No & \\
\hline OEC & OTH & Korea, Rep. & Yes & Yes \\
\hline $\mathrm{NOC}$ & $\mathrm{OTH}$ & Kuwait & No & No \\
\hline LIC & ECA & Kyrgyz Republic & Yes & Yes \\
\hline LIC & EAP & Lao PDR & No & Yes \\
\hline UMC & ECA & Latvia & Yes & Yes \\
\hline UMC & MNA & Lebanon & No & No \\
\hline LIC & AFR & Lesotho & Yes & Yes \\
\hline LIC & AFR & Liberia & No & No \\
\hline UMC & MNA & Libya & No & No \\
\hline $\mathrm{NOC}$ & OTH & Liechtenstein & Yes & No \\
\hline UMC & ECA & Lithuania & Yes & Yes \\
\hline OEC & $\mathrm{OTH}$ & Luxembourg & Yes & Yes \\
\hline $\mathrm{NOC}$ & $\mathrm{OTH}$ & Macao, China & No & \\
\hline LMC & ECA & Macedonia, FYR & No & Yes \\
\hline LIC & AFR & Madagascar & Yes & Yes \\
\hline LIC & AFR & Malawi & Yes & No \\
\hline UMC & EAP & Malaysia & Yes & Yes \\
\hline LMC & SAR & Maldives & Yes & Yes \\
\hline LIC & AFR & Mali & Yes & Yes \\
\hline UMC & MNA & Malta & Yes & Yes \\
\hline LMC & EAP & Marshall Islands & No & Yes \\
\hline LIC & AFR & Mauritania & Yes & Yes \\
\hline UMC & AFR & Mauritius & Yes & Yes \\
\hline UMC & AFR & Mayotte & No & \\
\hline UMC & LRC & Mexico & Yes & Yes \\
\hline LMC & EAP & Micronesia, Fed. Sts. & No & No \\
\hline LIC & ECA & Moldova & Yes & No \\
\hline $\mathrm{NOC}$ & OTH & Monaco & No & Yes \\
\hline LIC & EAP & Mongolia & Yes & Yes \\
\hline LMC & MNA & Morocco & Yes & Yes \\
\hline LIC & AFR & Mozambique & Yes & Yes \\
\hline LIC & EAP & Myanmar & No & No \\
\hline LMC & AFR & Namibia & Yes & No \\
\hline LIC & SAR & Nepal & Yes & No \\
\hline OEC & $\mathrm{OTH}$ & Netherlands & Yes & Yes \\
\hline $\mathrm{NOC}$ & $\mathrm{OTH}$ & Netherlands Antilles & No & \\
\hline NOC & OTH & New Caledonia & No & \\
\hline OEC & OTH & New Zealand & No & Yes \\
\hline LIC & LRC & Nicaragua & Yes & Yes \\
\hline LIC & AFR & Niger & No & Yes \\
\hline LIC & AFR & Nigeria & Yes & No \\
\hline NOC & $\mathrm{OTH}$ & Northern Mariana Islands & No & \\
\hline OEC & OTH & Norway & Yes & Yes \\
\hline UMC & MNA & Oman & Yes & No \\
\hline LIC & SAR & Pakistan & Yes & Yes \\
\hline UMC & EAP & Palau & No & \\
\hline UMC & LRC & Panama & Yes & Yes \\
\hline LIC & EAP & Papua New Guinea & Yes & No \\
\hline
\end{tabular}


Table A3: Extent of Reforms in ICT Sector as of 2004

\begin{tabular}{|c|c|c|c|c|}
\hline \begin{tabular}{|l} 
Income \\
Level (1)
\end{tabular} & $\begin{array}{l}\text { Geographic } \\
\text { Region (2) } \\
\end{array}$ & Country Name & Have Independent Regulatory Agency? (Yes/ No) & Have Private Participation? (Yes/No) \\
\hline LMC & LRC & Paraguay & Yes & No \\
\hline LMC & LRC & Peru & Yes & Yes \\
\hline LMC & EAP & Philippines & Yes & Yes \\
\hline UMC & ECA & Poland & Yes & Yes \\
\hline OEC & $\mathrm{OTH}$ & Portugal & Yes & Yes \\
\hline UMC & LRC & Puerto Rico & No & \\
\hline NOC & OTH & Qatar & No & Yes \\
\hline LMC & ECA & Romania & Yes & Yes \\
\hline LMC & ECA & Russian Federation & No & Yes \\
\hline LIC & AFR & Rwanda & Yes & Yes \\
\hline LMC & EAP & Samoa & No & No \\
\hline $\mathrm{NOC}$ & OTH & San Marino & No & Yes \\
\hline LIC & AFR & Sao Tome and Principe & No & Yes \\
\hline UMC & MNA & Saudi Arabia & Yes & Yes \\
\hline LIC & AFR & Senegal & Yes & Yes \\
\hline UMC & AFR & Seychelles & No & Yes \\
\hline LIC & AFR & Sierra Leone & No & No \\
\hline NOC & OTH & Singapore & Yes & Yes \\
\hline UMC & ECA & Slovak Republic & Yes & Yes \\
\hline NOC & $\mathrm{OTH}$ & Slovenia & Yes & Yes \\
\hline LIC & EAP & Solomon Islands & No & Yes \\
\hline LIC & AFR & Somalia & No & Yes \\
\hline LMC & AFR & South Africa & Yes & Yes \\
\hline OEC & OTH & Spain & Yes & Yes \\
\hline LMC & SAR & Sri Lanka & Yes & Yes \\
\hline UMC & LRC & St. Kitts and Nevis & No & \\
\hline UMC & LRC & St. Lucia & Yes & Yes \\
\hline LMC & LRC & St. Vincent and the Grenadines & Yes & Yes \\
\hline LIC & AFR & Sudan & Yes & Yes \\
\hline LMC & LRC & Suriname & Yes & No \\
\hline LMC & AFR & Swaziland & No & No \\
\hline OEC & $\mathrm{OTH}$ & Sweden & Yes & Yes \\
\hline OEC & $\mathrm{OTH}$ & Switzerland & Yes & Yes \\
\hline LMC & MNA & Syrian Arab Republic & No & No \\
\hline LIC & ECA & Tajikistan & No & Yes \\
\hline LIC & AFR & Tanzania & Yes & Yes \\
\hline LMC & EAP & Thailand & Yes & \\
\hline LIC & AFR & Togo & Yes & No \\
\hline LMC & EAP & Tonga & No & No \\
\hline UMC & LRC & Trinidad and Tobago & Yes & No \\
\hline LMC & MNA & Tunisia & Yes & No \\
\hline LMC & ECA & Turkey & Yes & No \\
\hline LMC & ECA & Turkmenistan & No & No \\
\hline LIC & AFR & Uganda & Yes & Yes \\
\hline LIC & ECA & Ukraine & No & No \\
\hline $\mathrm{NOC}$ & $\mathrm{OTH}$ & United Arab Emirates & No & Yes \\
\hline OEC & $\mathrm{OTH}$ & United Kingdom & Yes & Yes \\
\hline OEC & $\mathrm{OTH}$ & United States & Yes & Yes \\
\hline UMC & LRC & Uruguay & Yes & No \\
\hline LIC & ECA & Uzbekistan & No & No \\
\hline LMC & EAP & Vanuatu & No & Yes \\
\hline UMC & LRC & Venezuela, RB & Yes & Yes \\
\hline LIC & EAP & Vietnam & No & No \\
\hline $\mathrm{NOC}$ & OTH & Virgin Islands (U.S.) & No & \\
\hline LMC & MNA & West Bank and Gaza & No & \\
\hline LIC & MNA & Yemen, Rep. & No & No \\
\hline LMC & ECA & $\begin{array}{l}\text { Yugoslavia, FR } \\
\text { (Serbia/Montenegro) }\end{array}$ & No & Yes \\
\hline LIC & AFR & Zambia & Yes & No \\
\hline LIC & AFR & Zimbabwe & Yes & No \\
\hline
\end{tabular}


Notes to tables:

(1) The income level classification was made according to the WDI criteria:

* LIC: Low-income economies. Those in which 2001 GNI per capita was $\$ 745$ or less.

* LMC: Lower-middle-income economies. Those in which 2001 GNI per capita was between $\$ 745$ and $\$ 2,975$.

* UMC: Upper-middle-income economies. Those in which 2001 GNI per capita was between $\$ 2,976$ and $\$ 9,205$.

* OEC: High-income OECD. OECD countries in which 2001 GNI per capita was $\$ 9,206$ or more.

* NOC: High-income non-OECD. Non-OECD countries in which 2001 GNI per capita was $\$ 9,206$ or more.

(2) Composition of regions based on the World Bank's analytical regions for low and middle-income economies:

* EAP: East Asia and Pacific

* ECA: Europe and Central Asia

* LCR: Latin America and Caribbean

* MNA: Middle East and North Africa

* SAR: South Asia

* AFR: Sub-Saharan Africa

High income economies were classified as OTH 